EVS27

Barcelona, Spain, November 17-20, 2013

\title{
Current Fiscal Year (2012 - 2013) Status of the Hybrid and Electric Systems R\&D at the U.S. - DOE
}

\author{
David Howell ${ }^{1}$ \\ ${ }^{1}$ Vehicle Technologies Program, EE-2G, U.S. Department of Energy, \\ 1000 Independence Avenue, SW, Washington, DC 20585, USA \\ E-mail: David.Howell@ee.doe.gov
}

\begin{abstract}
This paper provides the latest information and progress overview (for the Fiscal Years 2012-2013) of the hybrid and electric systems (HES) R\&D projects funded by the Vehicles Technologies Office (VTO) of the U.S. Department of Energy (DOE). HES include battery R\&D, electric drive components, and vehicle \& systems simulation \& testing. Currently there is significant U.S. commitment to HES R\&D (\$156M in Fiscal Year 2013). Several technologies developed partially under VTO-sponsored projects have moved into commercial applications. DOE has supported the development of advanced HES technologies over the long term, leveraging resources and expertise from automobile manufacturers, battery, motor, and electronics developers, small businesses, national laboratories, and universities to address the market technical barriers for those technologies. The HES R\&D Team has had many significant accomplishments and continues to advance the state of the art for many technologies. The paper summarizes the most recent highlights for the three HES R\&D areas and U.S. industry highlights for the battery industry, in particular.
\end{abstract}

Keywords: Battery, Energy Storage, Simulation, PHEV, EV

\section{Introduction}

This paper provides an overview of the Fiscal Years (FYs) 2012-2013 Hybrid and Electric Systems (HES) R\&D projects funded by the Vehicles Technologies Office (VTO) of the U.S. Department of Energy (DOE). VTO spearheads the R\&D needed for a new generation of electricdrive vehicles, following a comprehensive research plan [1] which covers battery R\&D, electric drive components, and vehicle \& systems simulation \& testing. Status updates on HES $\mathrm{R} \& \mathrm{D}$ have been regularly provided at prior EVS meetings [e.g., 2-4]. VTO leverages significant resources (including those involving the automobile industry, suppliers, developers, national laboratories, and universities) to address the technical barriers preventing the commercialization of electric drive vehicles (EDVs). VTO works with automakers and other industry stakeholders through partnerships such as the U.S. DRIVE (United States Driving Research and Innovation for Vehicle efficiency and Energy sustainability) - for funding high-reward/high-risk research to enable improvements in critical components for more fuel efficient and cleaner vehicles. As shown in Table 1, there is significant U.S. commitment to HES - the FY 2013 budget of \$156 million is nearly three times its FY 2003 budget. 
Table 1: Recent HES R\&D budgets

\begin{tabular}{|lcccccc|}
\hline Fiscal Year (FY) & 2003 & 2004 & 2005 & 2006 & 2007 & 2008 \\
HES Budget (\$, Million) & $\$ 55.5$ & $\$ 57.3$ & $\$ 57.1$ & $\$ 55.6$ & $\$ 72.3$ & $\$ 92.1$ \\
\hline Fiscal Year (FY) & 2009 & 2010 & 2011 & 2012 & 2013 & 2014 \\
HES Budget (\$, Million) & $\$ 122.7$ & $\$ 142.3$ & $\$ 145.8$ & $\$ 164.9$ & $\$ 156.4$ & $\$ 310.2 *$ \\
\hline
\end{tabular}

\section{Barriers, Goals, and Strategies}

\subsection{Technical Barriers}

It has been recognized for some time that the technical barriers preventing the successful commercialization of advanced energy storage transportation technologies are associated with cost, performance, life, and abuse tolerance - of which cost is the overriding factor. Also, it is critical for any new vehicle technology (including advanced energy storage systems) to operate safely under both routine and extreme conditions (including abuse conditions of high temperature, overcharge, short circuit, etc.)

\subsection{Goals and Targets}

The commercialization of plug-in hybrid vehicles (PHEVs) and making them cost-competitive with conventional internal combustion engine vehicles is an important current VTO goal. This includes reducing the production cost of market-ready, high-energy, high-power batteries by $70 \%$ by 2014 (compared with their 2009 costs) and reducing the cost of the associated market-ready advanced power electronics and electrical machine (APEEM) system at least 60\% by 2015 (also compared with the 2009 costs). Technical targets for individual battery applications have been developed in collaboration with the United States Advanced Battery Consortium (USABC). Current targets for PHEV batteries are tabulated within the VTO program plan [1]. Additional performance targets (e.g., those for HEVs, EVs, and ultracapacitors) are available at the USABC website [5] and also reported in the VTO Energy Storage R\&D annual progress report [6]. For the APEEM and Vehicle Systems and Simulation Testing (VSST) activities (which are described in greater detail later in this paper) the technical targets for peak power, costs, etc. can be found in the corresponding sections of the VTO multiyear program plan [1].

\subsection{Strategies}

Technology development in collaboration with industry partners can enable the rapid integration of new technologies into production vehicles. VTO works with industry, universities, and national laboratories to support research on the nextgeneration energy storage and electric-drive technologies. To meet its EV/PHEV goals and to speed up the commercialization of advanced transportation technologies, VTO utilizes a multipronged approach. An example of its near-term measures includes its emphasis on clean energy initiatives like the $E V$ Everywhere Grand Challenge which focuses on the domestic production of cost-competitive PHEVs. Another example of near-term measures is its setting up of one-time manufacturing grants under the Recovery Act to accelerate the manufacture and deployment of the next generation of U.S.-made batteries and EDVs. Over the longer term, the VTO R\&D strategy involves funding topical research conducted at national laboratories and supporting technology development efforts of the industry by cost-sharing battery development. Further, APEEM research [7] is focused on developing new power electronics and electric motor technologies that will leapfrog current on-the-road technologies. In the same vein, the VSST activity [8] uses analytical and empirical tools to simulate vehicle systems, to verify performances, benchmark emerging technologies, and to validate the associated computer models. These short- and long-term measures are described in greater detail in the next sections.

\section{The EV Everywhere Grand Challenge}

DOE has in place a 10-Year Vision Plan entitled "EV Everywhere Grand Challenge” for facilitating the market feasibility of electric drive vehicles. $E V$ Everywhere would enable American innovators to rapidly develop and commercialize the next generation of technologies achieve levels of cost, range, and charging infrastructure necessary for widespread EDV deployment. VTO is 
collaborating with outside stakeholders on this initiative and also with DOE Office of Science, Office of Electricity, and the Advanced Research Projects Agency-Energy (ARPA-E). The EV Everywhere Blueprint [9] describes the steps needed to meet its overall goal and other

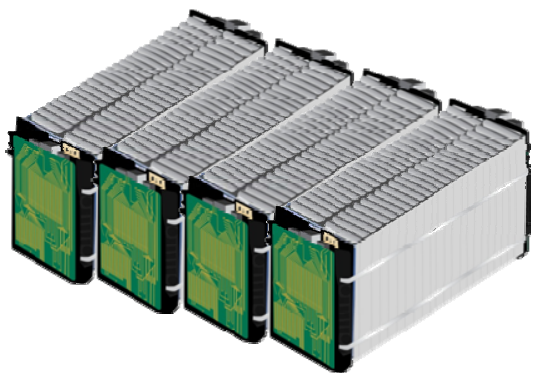

2012 Battery Technology $\$ 600 / \mathrm{kWh}, 100 \mathrm{Wh} / \mathrm{kg}, 200 \mathrm{Wh} / \mathrm{l}, 400 \mathrm{~W} / \mathrm{kg}$

Lithium-ion batteries in today's electric drive vehicles use a combination of positive active materials based on nickel, manganese, or iron; matched with a carbon or graphite negative electrode.

Figure 1: Battery Advancements Needed to Enable a Large Market Penetration of PEVs

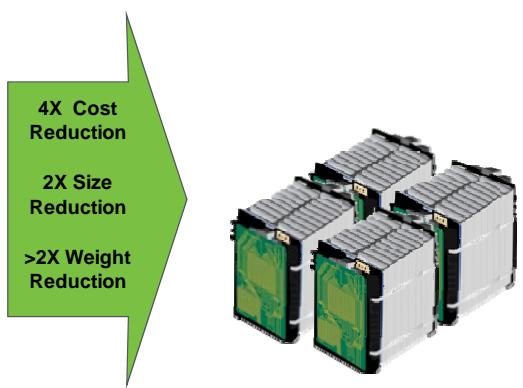

2022 Battery Technology

$\$ 125 / \mathrm{kWh}, 250 \mathrm{Wh} / \mathrm{kg}, 400 \mathrm{Wh} / \mathrm{l}, 2,000 \mathrm{~W} / \mathrm{kg}$

New concepts in lithium-ion technologies have the potential to more than double the performance and significantly reduce the cost. Beyond lithium-ion technologies (lithium metal, lithium sulfur, and lithium air) may also meet the challenge. aggressive, technology-specific "stretch goals" developed in consultation with stakeholders across the industry. Figure 1 identifies the battery advancements necessary for commercial feasibility in EDV application.

\section{HES Projects funded by the Recovery Act}

As part of the implementation of the 2009 economic stimulus package entitled American Recovery and Reinvestment Act of 2009 (Public Law 111-5) (ARRA) U.S. announced \$2.4 Billion in one-time manufacturing grants [10] to accelerate the manufacture and deployment of the next generation of U.S.-made batteries and EDVs. The awards, distributed across the U.S., included $\$ 1.5$ billion in grants to U.S.-based manufacturers to produce batteries and their components and expand battery recycling capacity, approximately $\$ 500 \mathrm{M}$ to produce electric drives and their components, plus $\$ 400 \mathrm{M}$ to purchase, deploy and evaluate PHEVs and all- electric vehicles for test demonstrations, to install electric charging infrastructures, and to support relevant outreach activities. These led to numerous new projects for manufacturing advanced batteries as well as EDV components and for conducting deployment and demonstration activities. The manufacturing areas further include material supply, cell components, cell fabrication, pack assembly, and recycling. The individual grants are described in detail in the energy storage $R \& D$ annual progress report [6]. All ARRA manufacturing facility projects for battery/materials have been initiated and production has begun at most of them (see Table 2). 
Table 2: Current Production Status for Some Battery Facilities Funded by ARRA Grants.

\begin{tabular}{|c|c|c|}
\hline $\begin{array}{l}\text { Facility } \\
\text { Type }\end{array}$ & Company & Facility Location (Status) \\
\hline \multirow[t]{9}{*}{$\begin{array}{l}\text { Cell \& Pack } \\
\text { Production }\end{array}$} & A123Systems & $\begin{array}{l}\text { Cathode, cell, \& pack assembly, Livonia \& Romulus, MI (Production } \\
\text { established) }\end{array}$ \\
\hline & Dow Kokam & Cell \& pack assembly, Midland, MI (Production in pre-buy-off run) \\
\hline & East Penn & Advanced Lead Acid battery in PA (Production established) \\
\hline & EnerDel & $\begin{array}{l}\text { Cell production \& pack assembly at Fishers \& Mt Comfort, IN } \\
\text { (Commercial pack assembly - cells sourced from Korean affiliate) }\end{array}$ \\
\hline & Exide & Advanced lead acid battery, Columbus, GA (Production established) \\
\hline & $\begin{array}{l}\text { General } \\
\text { Motors }\end{array}$ & $\begin{array}{l}\text { Battery pack assembly at Brownstown, MI (Successful start of regular } \\
\text { production (SORP) for the Chevrolet Volt EREV battery pack) }\end{array}$ \\
\hline & $\begin{array}{l}\text { Johnson } \\
\text { Controls } \\
\end{array}$ & $\begin{array}{l}\text { Cell production \& pack assembly, Holland, MI (Production } \\
\text { established) }\end{array}$ \\
\hline & LG Chem, MI & $\begin{array}{l}\text { Cell \& pack capability, Holland, MI (Phase I facility production } \\
\text { established) }\end{array}$ \\
\hline & SAFT & Cell production, Jacksonville, FL (First production line established) \\
\hline \multirow[t]{2}{*}{ Cathode } & TODA & Battle Creek, Michigan (Production established) \\
\hline & BASF & Elyria, OH (Production established) \\
\hline \multirow[t]{3}{*}{ Anode } & EnerG2 & Albany, OR (Production established) \\
\hline & FutureFuel & Batesville, AR (Production established) \\
\hline & Pyrotek & Sanborn, NY (Production established) \\
\hline \multirow[t]{2}{*}{ Separator } & Celgard & Charlotte, NC \& Concord, NC (Production established) \\
\hline & Entek & Lebanon, OR (Engineering scoping completed) \\
\hline \multirow[t]{2}{*}{ Electrolyte } & Honeywell & Buffalo, NY \& Metropolis, IL (Li-salt pilot plant operational) \\
\hline & $\begin{array}{l}\text { Novolyte } \\
\text { (BASF) }\end{array}$ & Zachary, LA (Equipment installation) \\
\hline Lithium & $\begin{array}{l}\text { Chemetall } \\
\text { Foote }\end{array}$ & $\begin{array}{l}\text { Silver Peak, NV \& Kings Mountain, NC (Lithium hydroxide } \\
\text { production established) }\end{array}$ \\
\hline $\begin{array}{l}\text { Cell } \\
\text { Hardware }\end{array}$ & $\begin{array}{l}\text { H\&T } \\
\text { Waterbury }\end{array}$ & Waterbury, CT (Production established) \\
\hline
\end{tabular}

\section{Hybrid Electric Systems R\&D}

\subsection{Energy Storage R\&D}

Multiple DOE offices support energy storage R\&D. These include the Office of Basic Energy Sciences (BES) (doing fundamental research to understand, predict, and control matter and energy at electronic, atomic, and molecular levels), ARPA-E (conducting high-risk, translational research with potential for significant near-term commercial impact), the Office of Electricity Delivery and Energy Reliability (OE) (R\&D on modernizing the electric grid, enhancing energy infrastructure, and mitigating impacts of supply disruptions), and the Office of Energy Efficiency and Renewable Energy (EERE) (supporting work through VTO on advanced clean, reliable, sustainable, and affordable technologies which would reduce energy consumption). The R\&D postures of the various offices are consistent with the applicable technology readiness levels (TRLs) of their supported technologies. Technologies at a lower TRL generally fall within the domain of BES and ARPA-E, whereas those at higher TRLs would generally be covered by EERE. The EERE energy storage $R \& D$ projects (see Table 3 ) cover a range of activities, from hardware development with industry to mid-term R\&D and focused fundamental research - all of them organized to complement each other. DOE maintains a close partnership with the automotive industry through the USABC to support the development of such technologies. The goal is to help develop a U.S. domestic advanced battery industry whose products can meet USABC technical goals. More information on individual energy storage R\&D projects is available in the VTO Energy Storage $\mathrm{R} \& \mathrm{D}$ annual progress report [6]. 
Table 3: An overview of EERE energy storage R\&D projects in FY 2012 (from [6])

\begin{tabular}{|c|c|c|}
\hline $\begin{array}{l}\text { Project } \\
\text { Area }\end{array}$ & Project Topic & Participants \\
\hline \multirow{11}{*}{$\begin{array}{l}\text { Battery } \\
\text { development, } \\
\text { system } \\
\text { analysis, and } \\
\text { testing }\end{array}$} & EV Batteries (High Energy) & Envia Systems, Cobasys, Quallion \\
\hline & PHEV Batteries (High Energy) & Johnson Controls, LG Chem - Michigan \\
\hline & $\begin{array}{l}\text { HEV and LEESS Batteries (High } \\
\text { Power) }\end{array}$ & Maxwell \\
\hline & $\begin{array}{l}\text { Technology Assessment (EV, or } \\
\text { LEESS) }\end{array}$ & K2 Energy, Leyden Energy, Actacell, Farasis \\
\hline & $\begin{array}{l}\text { Advanced lithium-ion Battery (Cell } \\
\text { Materials) }\end{array}$ & $\begin{array}{l}\text { Amprius, Dow Kokam, Nanosys, 3M, Applied } \\
\text { materials, Seeo Inc., Pennsylvania State } \\
\text { University }\end{array}$ \\
\hline & Low-cost Manufacturing Processes & JCI, Miltec UV, A123Systems \\
\hline & $\begin{array}{l}\text { Inactive materials/components } \\
\text { Reduction }\end{array}$ & Optodot, Denso \\
\hline & Advanced Materials and Processing & $\begin{array}{l}\text { ENTEK Membranes, 3M, FMC, Sion Power, } \\
\text { BASF, Angstron, North Carolina State University, } \\
\text { EnerDel, TIAX, A123Systems, Small Business } \\
\text { Innovation Research (several projects) }\end{array}$ \\
\hline & Systems Analysis & TIAX, ANL, NREL \\
\hline & Battery Testing & ANL, INL, SNL, NREL \\
\hline & $\begin{array}{l}\text { Computer-aided Engineering of } \\
\text { Batteries }\end{array}$ & $\begin{array}{l}\text { NREL, ORNL, GM/Ansys, CD-Adapco, Ford/EC } \\
\text { Power }\end{array}$ \\
\hline \multirow[t]{4}{*}{$\begin{array}{l}\text { Applied } \\
\text { Battery } \\
\text { Research }\end{array}$} & $\begin{array}{l}\text { Materials Research } \\
\text { Cell Components and Composition } \\
\text { ABR: Anodes } \\
\text { ABR: Cathodes } \\
\text { ABR: Electrolytes }\end{array}$ & $\begin{array}{l}\text { ANL ( } 2 \text { projects), LBNL, NREL ( } 2 \text { projects), } \\
\text { ORNL ( } 2 \text { projects) } \\
\text { ANL ( } 4 \text { projects) } \\
\text { ANL ( } 2 \text { projects), ARL, JPL, INL }\end{array}$ \\
\hline & $\begin{array}{l}\text { Modeling, Diagnostics, and } \\
\text { Performance Studies }\end{array}$ & ANL (3 projects), LBNL, INL \\
\hline & Abuse Diagnostics and Mitigation & BNL, ANL, SNL, LBNL \\
\hline & $\begin{array}{l}\text { Applied Research Facilities } \\
\text { Battery Materials Pilot Production } \\
\text { Post-Test Diagnostics } \\
\text { Battery Electrode/Cell Production }\end{array}$ & $\begin{array}{l}\text { ANL ( } 2 \text { projects) } \\
\text { ANL } \\
\text { ANL ( } 2 \text { projects) }\end{array}$ \\
\hline \multirow[t]{6}{*}{$\begin{array}{l}\text { Exploratory } \\
\text { Technology } \\
\text { Research }\end{array}$} & Cathodes & $\begin{array}{l}\text { MIT ( } 2 \text { projects), LBNL (4 projects), University } \\
\text { of Texas, HQ, BNL, U. Mass, ANL, PNNL, } \\
\text { ORNL ( } 2 \text { projects) }\end{array}$ \\
\hline & Anodes & $\begin{array}{l}\text { University of Pittsburgh, LBNL (2 projects), } \\
\text { University of Texas, SUNY, PNNL, ANL, Drexel } \\
\text { University, NREL, University of Colorado, Penn } \\
\text { State University, Southwest Research Institute, } \\
\text { Stanford University, ORNL }\end{array}$ \\
\hline & Electrolytes & $\begin{array}{l}\text { UCB, LBNL, University of Utah, CWRU, ANL, } \\
\text { NCSU, University of Rhode Island, University of } \\
\text { Texas, Arizona State University, ORNL }\end{array}$ \\
\hline & $\begin{array}{l}\text { Cell Analysis, Modeling, and } \\
\text { Fabrication }\end{array}$ & $\begin{array}{l}\text { LBNL ( } 5 \text { projects), University of Michigan, } \\
\text { ORNL ( } 2 \text { projects), MIT }\end{array}$ \\
\hline & Energy Frontier Research Centers & ANL \\
\hline & $\begin{array}{l}\text { Beyond-Lithium Research } \\
\text { (Integrated Lab-initiated Industry } \\
\text { Research Projects) }\end{array}$ & ANL, LBNL, ORNL \\
\hline
\end{tabular}




\subsubsection{Advanced Battery Development, Systems Analysis, and Testing}

A significant part of DOE energy storage R\&D includes advanced battery development, systems analysis, and testing. It includes systems and materials development projects, systems analysis projects, and battery testing projects. Battery technologies are evaluated according to the USABC Battery Test Procedures Manual (for EV batteries) [11], the Partnership for a New Generation of Vehicles (PNGV) Battery Test Procedures Manual (for HEV batteries) [12], or the PEV test procedure manual [13]. Private battery developers receive cost-shared funding for technology development. Several technologies developed partially under VTO-sponsored projects have moved into commercial applications over time.

\subsubsection{Applied Battery Research}

The applied R\&D program entitled Applied Battery Research (ABR) for transportation assists industrial developers of high-energy/high-power lithium-ion batteries meet the US-DRIVE longterm battery-level PHEV energy density ( 200 $\mathrm{Wh} / \mathrm{kg}$ ) goal, while satisfying cost, life, abuse tolerance, and low-temperature performance goals. ABR projects cover materials development, calendar and cycle life studies, and abuse tolerance studies, utilizing the expertise of six national laboratories, industry, and several universities toward this end.

\subsubsection{Focused Fundamental Research}

The Focused Fundamental Research activity, also called the Batteries for Advanced Transportation Technologies (BATT) activity, addresses fundamental issues of chemistries and materials associated with lithium batteries. It attempts to gain insight into system failures, develops models to predict failure and to optimize systems, and researches new and promising materials. It emphasizes the identification and mitigation of failure modes, coupled with materials synthesis and evaluation, advanced diagnostics, and improved electrochemical models. Battery chemistries are monitored continuously with periodic substitution of more promising components based on advice from within this activity, from outside experts and based on assessments of world-wide battery R\&D. The work is carried out by a team which includes the Lawrence Berkeley National Laboratory (LBNL) and several other national labs, universities, and commercial entities. More information on BATT appears at its website [14].

\subsubsection{Energy Storage Collaborative R\&D}

In addition to the R\&D described above, many VTO-funded small business innovation research (SBIR) projects focused on new battery materials and components provide valuable support to EV and HEV battery development efforts. DOE also has extensive ongoing coordination efforts with other government agencies, e.g., the Chemical Working Group of the Interagency Advanced Power Group (IAPG) and technical meetings sponsored by other government agencies. DOE is a member of the Executive Committee of the International Energy Agency (IEA) Implementing Agreement on Hybrid and Electric Vehicles and participates in various Annexes of the Implementing Agreement. It attends the IEA Executive Committee meetings held in various countries and provides status updates on other implementing agreements.

\subsection{Vehicle \& Systems Simulation \& Testing (VSST)}

The VSST mission is to evaluate the technologies and performance characteristics of advanced automotive power-train components and subsystems in vehicle systems. Its systems integration and validation evaluations employ modelling and simulation, laboratory testing, and operational fleet testing. VSST tools forecast national-level energy and environmental parameters (e.g., oil use, infrastructure economics, and greenhouse gas analyses) and conduct vehicle-level simulations. Hardware-in-the-loop (HIL) simulation allows hardware components to be tested in the laboratory without requiring a prototype vehicle. During benchmarking, both production vehicles and component technologies are extensively tested to verify any significant advances over current technologies. VSST works with industry partners to accurately measure realworld performance of advanced technology vehicles using a testing regime developed in partnership with industry stakeholders. In addition to baseline performance testing, fleet testing and accelerated reliability testing are also carried out. Table 4 contains an overview of the project features in each of the six project areas for FY 2012. Detailed information on individual VSST projects appears in the current VSST Annual Progress Report [7]. 
Table 4: An Overview of Vehicle Systems and Simulation Testing Research projects in FY 2012 (from [7])

\begin{tabular}{|c|c|c|}
\hline Project Area & Project Group & Participants \\
\hline \multirow{6}{*}{$\begin{array}{l}\text { Industry Awards for } \\
\text { Technology } \\
\text { Development and } \\
\text { Demonstration }\end{array}$} & $\begin{array}{l}\text { PHEV Technology } \\
\text { Acceleration and } \\
\text { Demonstration Activity }\end{array}$ & Chrysler, Ford, General Motors \\
\hline & $\begin{array}{l}\text { Transportation } \\
\text { Electrification }\end{array}$ & $\begin{array}{l}\text { Cascade Sierra Solutions ,Coulomb Technologies, } \\
\text { Chrysler, ECOtality North America, General } \\
\text { Motors, Navistar, South Coast Air Quality } \\
\text { Management District, Smith Electric Vehicles }\end{array}$ \\
\hline & SuperTruck & Cummins, Daimler, Navistar, Volvo \\
\hline & $\begin{array}{l}\text { Wireless Charging Light } \\
\text { Duty }\end{array}$ & $\begin{array}{l}\text { Hyundai North America \& Mojo Mobility, ORNL } \\
\text { \& EVATRAN }\end{array}$ \\
\hline & $\begin{array}{l}\text { Zero Emissions Cargo } \\
\text { Transport }\end{array}$ & $\begin{array}{l}\text { South Coast Air Quality Management District, } \\
\text { Houston-Galveston Area Council (2 projects) }\end{array}$ \\
\hline & $\begin{array}{l}\text { Energy Load Reduction \& } \\
\text { Energy Management, } \\
\text { Advanced HVAC } \\
\text { Technologies, \& Cabin } \\
\text { Preconditioning }\end{array}$ & To be announced. \\
\hline \multirow{2}{*}{$\begin{array}{l}\text { Laboratory and } \\
\text { Field Evaluations }\end{array}$} & Light Duty & INL, ANL (8 projects), NREL(2 projects) \\
\hline & Medium/Heavy Duty & ORNL (2 projects), NREL (4 projects) \\
\hline \multirow{2}{*}{$\begin{array}{l}\text { Vehicle Modeling } \\
\text { and Simulation }\end{array}$} & Light Duty & ANL (10 projects), NREL, ORNL (4 projects) \\
\hline & Medium/Heavy Duty & ANL, NREL (3 projects), ORNL \\
\hline $\begin{array}{l}\text { Component/Systems } \\
\text { Evaluation }\end{array}$ & NA & ANL (3 projects), ORNL(3 projects) \\
\hline Codes and Standards & NA & $\begin{array}{l}\text { ANL ( } 7 \text { projects), ORNL ( } 2 \text { projects), PNNL ( } 2 \\
\text { projects) }\end{array}$ \\
\hline \multirow{4}{*}{$\begin{array}{l}\text { Vehicle Systems } \\
\text { Optimization }\end{array}$} & Aerodynamics & LLNL \\
\hline & Fast \& Wireless Charging & INL, NREL, ORNL \\
\hline & Friction \& Wear & ANL (2 projects) \\
\hline & Thermal Control & ANL (4 projects) \\
\hline
\end{tabular}

\subsection{Advanced Power Electronics and Electric Motors (APEEM) R\&D}

The APEEM activity provides support and guidance for many cutting-edge automotive technologies under development. It is focused on the requirement that an affordable electric traction drive system will need to attain weight, volume, and cost targets for the power electronics and electrical motors subsystems of the traction drive system. Its R\&D areas include novel traction motor designs for increased power density and lower cost; inverter technologies with more efficient topologies; converter concepts for reduced component counts and integrated functionalities to decrease size, weight, and cost; new on-board battery charging concepts; more effective thermal control and packaging technologies; and integrated motor/inverter concepts. The Advanced Thermal Management for Vehicle Power Electronics and Electric Motors research is focused on developing thermal management technologies that enable advanced power electronics and electric motor technologies that are efficient, small, light, low cost, and reliable. It includes thermal system integration, heat transfer technologies, and thermal stress/reliability studies. In addition, ORNL's Power Electronics and Electric Machinery Research Center conducts fundamental research, evaluates hardware, and provides other technical contributions to the APEEM activity. Table 5 contains an overview of the projects in each of the APEEM task areas. More detailed information on individual APEEM R\&D projects is found in the APEEM Annual Progress Report [8]. 
Table 5: An overview of APEEM Research projects, FY 2012 (from [8])

\begin{tabular}{|l|l|l|}
\hline \multicolumn{2}{|c|}{ Project Area } & \multicolumn{1}{c|}{ Participants } \\
\hline $\begin{array}{l}\text { Research and } \\
\text { Technology } \\
\text { Development }\end{array}$ & Power Electronics & $\begin{array}{l}\text { ORNL (8 projects), ANL, SNL, PSU, NASA-Glenn, GM, } \\
\text { Delphi }\end{array}$ \\
\cline { 2 - 3 } & Electric Motor & ORNL (2 projects), Ames Laboratory, GE, UQM \\
\cline { 2 - 3 } & Systems & ORNL (2 projects), SBIR \\
\cline { 2 - 3 } & Thermal Management & NREL (6 projects) \\
\hline $\begin{array}{l}\text { ARRA Awards } \\
(10)\end{array}$ & $\begin{array}{l}\text { Allison Transmission, Delphi, Ford, GM, KEMET, Magna E-Car Systems, Powerex, } \\
\text { Remy, SBE, UQM Technologies }\end{array}$ \\
\hline
\end{tabular}

\section{Recent Highlights}

The R\&D funded by HES has led to significant accomplishments and its technology breakthroughs are utilized in many new commercial applications. The following is a brief summary of some key technical accomplishments, most of which are described in greater detail in the corresponding VTO annual progress reports $[6,7,8]$.

\subsection{Electric Drive Vehicle Market}

\subsubsection{U.S. Electric Drive Vehicle Sales}

Despite obstacles, the U.S. EDV market is growing. Sales of EDVs tripled in 2012 (see Figure 2). PEV sales grew rapidly with 2012 U.S. sales being over 50,000 vehicles, three times the 2011 sales. Popular PHEV models are outselling more than half of all vehicle models sold in the U.S. Also, 15 new hybrid, PHEV and all-electric vehicles are expected to be in production by nine different automakers in model years 2013 and 2014.

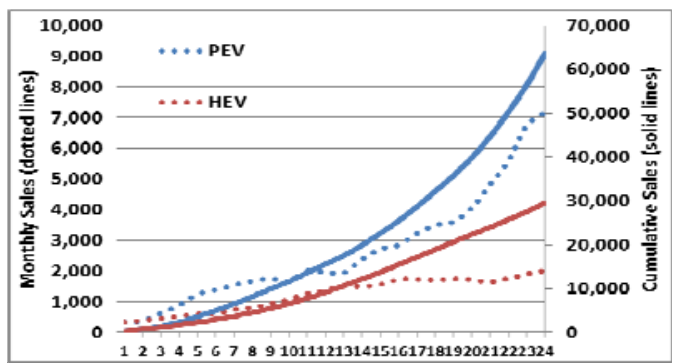

(Source: HybridCars.com)

Figure 2: New PEV sales compared to hybrid electric vehicle (HEV) sales over their respective 24 month introductory periods.

\subsubsection{Commercial Applications of DOE- supported Technologies}

Several technologies developed partially under VTO-sponsored projects have moved into commercial applications. HEVs on the market from BMW and Mercedes are using Li-ion technology developed under projects with Johnson Controls-Saft (JCS). Li-ion battery technology developed with DOE funding at LG Chem is being used in GM's Chevrolet Volt extended-range electric vehicle and has been selected for the Ford Focus EV battery.

\subsubsection{Recovery Act facilities}

All Recovery Act battery facility projects are on track - with production underway (more information on them appeared in section 4.)

\subsubsection{New SAE J1772 Combo Connector Standard}

The SAE EV and PHEV Conductive Charge Coupler J1772 charging standard (see Figure 3) for North American cars was published in October 2012 [15]. This new charging outlet design uses paired couplers for both AC and DC charging and can reduce the charging time from 8 hours to as little as 20 minutes.
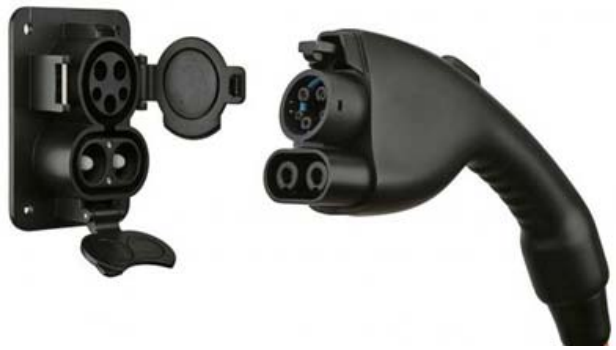

Figure 3: SAE J1772 Electric Vehicle and Plug in Hybrid Electric Vehicle Conductive Charge Coupler

\subsubsection{Tesla Model S Car of the Year Award}

In June 2012, Tesla started deliveries of its Model S vehicle which received the Motor Trend Car of the Year award - the first non-internal combustion engine-powered winner in the award's history. The Model $\mathrm{S}$ is available in 4 different configurations -from a $40 \mathrm{kWh}$ battery pack (estimated range: 160 miles) to an $85 \mathrm{kWh}$ battery pack (EPA official range: 265 miles). 


\subsubsection{DOE Clean Cities Projects for EV Readiness}

In November 2012, DOE awarded \$11 million to 20 Clean Cities alternative fuel projects to diversify U.S. fuel economy and to facilitate the market adoption of advanced vehicles. Of those, several are related to EV and EVSE infrastructure deployment.

\subsection{Batteries - High Energy}

\subsubsection{Reduced Cost Cathode Materials in Production}

BASF scaled-up and reduced the production cost for three nickel/ cobalt/manganese (NCM) cathode materials. Two of those materials (NCM 111 and NCM 523) are in production in BASF's plant in Elyria Ohio, and the NCM 424 will be produced in the production plant in the first quarter of 2013. NCM 111 and NCM 424 were qualified for use in EV and PHEV applications through independent cycle life testing of over 1,400 deep discharge cycles.

\subsubsection{New Synthesis Approach for High- energy Cathode Materials}

ANL developed a new synthesis approach for the high-energy, lithium-rich, manganese-rich layered-layered cathode materials that significantly reduced voltage fade on high voltage cycling. The performance of a cathode synthesized via a $\mathrm{Li}_{2} \mathrm{MnO}_{3}$ precursor shows high capacities of $\sim 250 \mathrm{mAh} / \mathrm{g}$ at $\sim \mathrm{C} / 15$, and $\sim 200$ $\mathrm{mAh} / \mathrm{g}$ at $\sim 1 \mathrm{C}$ rates. It displays good stability and capacity retention over extended cycling to high voltage.

\subsubsection{High Capacity Hollow Si Nanofiber Anodes}

Stanford University developed hollow silicon nanofibers as a new approach to address the issues of volume expansion and solid electrolyte interphase stability in $\mathrm{Si}$ anodes. Electrodes with the $\sim 600 \mathrm{~nm}$ diameter fibers demonstrated over 6,000 cycles in a half cell at a $5 \mathrm{C}$ rate at a capacity twice that of traditional carbon anodes.

\subsection{Batteries - Improved Power}

\subsubsection{Improved Performance through Particle Morphology Control}

LBNL identified the importance of particle morphology on $\mathrm{Li}$ transport in the 5-volt nickel/manganese spinel $\quad\left(\mathrm{LiNi}_{0.5} \mathrm{Mn}_{1.5} \mathrm{O}_{4}\right)$ cathode material. The study suggests that $\mathrm{Li}$ transport in the $\mathrm{Ni} / \mathrm{Mn}$ spinel is likely limited by the movement of phase boundaries.

\subsubsection{Improved Rate Capablity of High- voltage Cathode Material}

LBNL and collaborators investigated the 5-volt nickel/manganese spinel $\left(\mathrm{LiNi}_{0.5} \mathrm{Mn}_{1.5} \mathrm{O}_{4}\right)$ cathode material. The study determined that disorder of the Ni-Mn components resulted in improved rate capability and that high levels of $\mathrm{Mn}^{3+}$ played little role with regard to cycleability/rate.

\subsection{Batteries - Improved Life and Abuse Tolerance}

\subsubsection{Improved Safety through ALD Coating}

BNL used X-ray diffraction to study the stability of high energy cathode materials, with and without an ALD coating of $\mathrm{Al}_{2} \mathrm{O}_{3}$. The improvement in thermal stability obtained by the ALD coating may enhance the safety of the materials.

\subsubsection{Lithium-ion Electrolytes with Wide Temperature Ranges}

The Jet Propulsion Lab (JPL) developed new electrolytes for $\mathrm{Li}$-ion batteries which would significantly improve performance at low temperature while maintaining life at high temperature. Excellent performance was observed down to $-50^{\circ} \mathrm{C}$, with over $75 \%$ of the roomtemperature capacity being delivered at $2 \mathrm{C}$ rates.

\subsection{New Battery Technologies}

\subsubsection{Progress in Beyond-Li-ion Technologies}

LBNL, ANL and ORNL have partnered in a series of projects that utilize recent advances in ceramic electrolyte materials, polymer science, and materials characterization to stabilize lithium metal anodes. Inorganic solid state lithium-ion conductors have been proposed as protective electrolyte layers in a lithium metal cell that contains a second, liquid electrolyte in contact with the cathode. $\mathrm{Li}_{7} \mathrm{La}_{2} \mathrm{Zr}_{3} \mathrm{O}_{12}$ shows great promise for these applications thanks to its high lithium conductivity. The team studied the conditions that lead to impurity formation and developed a protocol to produce dense sintered membranes and thin films. 


\subsection{New Tools, Facilities, and Techniques}

\subsubsection{Cell Fabrication with Advanced Battery Materials}

ANL's Cell Fabrication Facility (CFF) allows promising next-generation battery materials to be tested at industrially relevant cell sizes. It enables scientists to manufacture both pouch and 18650 battery cells and electrodes for research. Dozens of cells with high-energy lithiummanganese-rich (LMR-NMO) cathodes were built in the CFF to investigate the voltage fade phenomenon.

\subsubsection{Scale-up of Promising Materials for Industry evaluation}

ANL's Materials Engineering Research Facility (MERF) was established to determine fast and economical ways of producing large quantities of advanced battery materials for commercial testing. A redox shuttle material, an electrolyte additive that enhances the safety of Li-ion batteries during overcharge, was scaled-up from a 1-gram bench-scale process to multi-kilogram production. The new scaled-up process costs 20 times less and generates 50 times less waste than the bench-scale process.

\subsubsection{Modeling of Li-ion Battery Performance and Cost}

ANL's Battery Performance and Cost (BatPaC) model was expanded to include many new features. Over 465 unique downloads have occurred, primarily from industrial users.

\subsubsection{Technologies for Improved Safety of Li-ion Batteries}

TIAX developed methods to induce Li-ion cell internal shorts and thermal runaway during otherwise normal operation. It developed a technology to detect growing internal shorts early on and is maturing these technologies for implementation in vehicle-size cells and packs.

\subsubsection{STAR-CCM $+{ }^{\mathrm{TM}}$}

CD-adapco, together with Battery Design, Johnson Controls, and A123 Systems, developed a thermally coupled battery design tool for lithium-ion battery systems. An initial version of the code is now in the public domain.

\subsubsection{AutoLion $^{\mathrm{TM}}$}

EC Power developed a thermally coupled lithiumion battery model for large-format $\mathrm{Li}$-ion cell/pack design, called AutoLion ${ }^{\mathrm{TM}}$. It captures the complex interaction between temperature and battery performance and calculates thermal and electrochemical outputs.

\subsection{VSST Highlights}

\subsubsection{Advanced Vehicle Test Activity (AVTA)}

AVTA has accumulated data on advanced technology electric drive vehicle performance and charging patterns over 104 million test miles and is collecting 1 million additional test miles every 6 days. The data collection has totalled 11,500 electric-drive vehicles (representing 119 models). The data describes the operational characteristics for 91 models within the BEV, PHEV, and Extended Range Electric Vehicle (EREV) categories.

\subsubsection{Vehicle Mass Impact Study}

A study quantified the vehicle mass impact on road force and energy consumption for ICE, HEV, and BEV vehicles (see Figure 4). Coast down and dynamometer testing was conducted on an ICE, $\mathrm{HEV}$, and BEV vehicle at several test weights (both above and below curb weight) to determine the impact of vehicle mass change on road load forces and energy consumption.

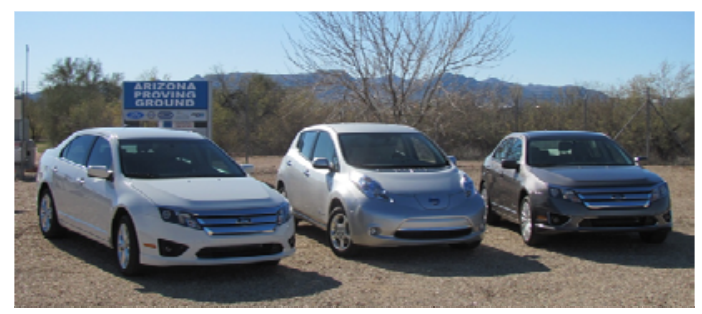

Figure 4: Vehicle Mass Impact Test Vehicles [7]

\subsubsection{Auxiliary Load Impact Study}

This study quantified the impact of auxiliary loads via in-depth thermal testing of a PHEV and BEV. It performed controlled chassis dynamometer testing on 2012 model year Chevrolet Volt PHEV and 2011 model year Nissan Leaf to determine impact on performance and range with cold and hot ambient temperatures of $20^{\circ} \mathrm{F}$ and $95^{\circ} \mathrm{F}$, respectively (see Figure 5). 


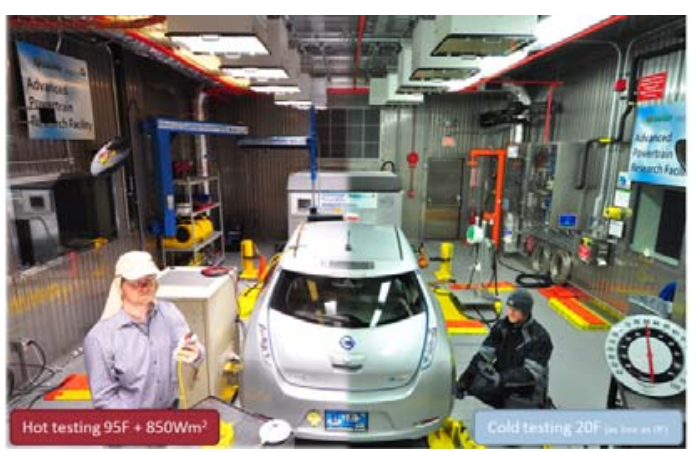

Figure 5: BEV testing displayed at $95^{\circ} \mathrm{F}$ with solar emulation on the left and testing at cold ambient temperatures on the right (ANL facility)

\subsubsection{Wireless PEV Charging Development/ Demonstration}

This activity completed Wireless PEV Charging Development/Demonstration Phase 2 and awarded two new Development, Integration, and Demonstration projects to Industry teams. Wireless power transfer (WPT) charging of EV's is an emerging technology that is finding widespread and rapid appeal as a safe, convenient and flexible means of charging.

\subsection{APEEM Highlights}

\subsubsection{High Power Traction Motor}

The GE Global Research "Alternative HighPerformance Motors with Non-Rare Earth Materials” project is developing a higher power density traction motor at low-cost while eliminating or reducing need for rare-earth materials. GE evaluated multiple motor topologies and completed preliminary downselect of 3 designs that will be built and tested.

\subsubsection{Advanced Inverter}

Delphi is to produce an advanced inverter (see Figure 6) with integrated controller incorporating advanced packaging innovations and new DC bus capacitor technologies. National lab expertise utilized for this project include capacitor development and testing (ANL and ORNL), power device characterization/ system modelling (ORNL), thermal/heat exchanger experiments and interface material characterization (NREL), and inverter system testing (ORNL).

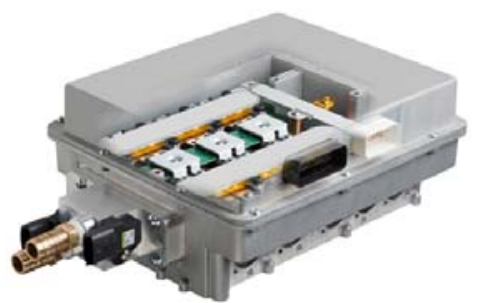

Figure 6: Delphi inverter with integrated controller [8]

\subsubsection{Novel Polymer Dielectric Capacitor}

Researchers at SNL developed polymer thin film capacitors for use in HEV inverters (see Figure 7) using a novel polymer dielectric material (price $<\$ 0.02 / \mu \mathrm{F}$ ) and have increased energy densities that could operate at elevated temperature environments and support the introduction of $105^{\circ} \mathrm{C}$ engine coolant cooled inverters. The projected benefits include increased inverter reliability and larger ripple currents as a result of the dielectric materials.
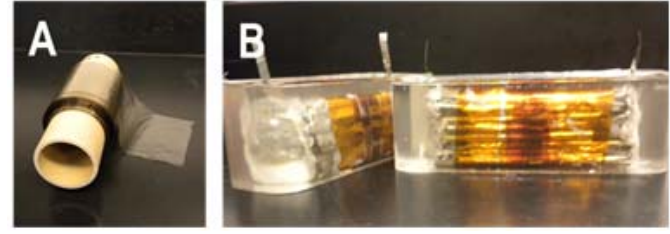

Figure 7: (A) An image of the $\sim 100 \mathrm{~m}$ roll of high temperature dielectric and (B) Packaged high temperature capacitor [8]

\section{Conclusions}

DOE Vehicle Technologies R\&D activities for hybrid electric systems are focused on advanced batteries, power electronics and electric machines, and simulation and testing for transportation applications and currently emphasize PHEVs. The past successful commercialization of DOE-funded batteries is a testimony to the success already achieved by the DOE-USABC cooperative program. Future advances in HES technologies will be leveraged with the progress in other enabling technologies (e.g., heat engines, lightweight materials, and fuels) to reach the challenging VTO goals. The Program will continue to reassess longer-term candidate technologies for propulsion systems promising performance, life, and cost benefits. 


\section{References}

[1] Office of Vehicle Technologies, Vehicle Technologies Multi-Year Program Plan, 2011-2015 http://www1.eere.energy.gov/ vehiclesandfuels/pdfs/program/vt_mypp_20 11-2015.pdf, accessed on 2013-06-20.

[2] Howell, D., Hybrid and Electric Systems $R \& D$ at DOE: Fiscal Year 2011-2012 Status, the 26th International Battery, Hybrid and Fuel Cell Electric Vehicle Symposium (EVS26), Los Angeles, California, May 6-9, 2012.

[3] Howell, D., FY 2009 Status Overview of D.O.E. Hybrid and Electric Systems R\&D, the 25th World Battery, Hybrid and Fuel Cell Electric Vehicle Symposium \& Exhibition, Shenzhen, China, Nov. 2010.

[4] Howell, D., et al., Current Status of D.O.E.funded $R \& D$ on Energy Storage for Automotive Applications, the 24th International Battery, Hybrid and Fuel Cell Electric Vehicle Symposium and Exhibition, Stavanger, Norway, May 2009.

[5] United States Advanced Battery Consortium (USABC)/ USCAR, http://www.uscar.org/guest/view_team.php? teams id=12, accessed on 2013-06-20.

[6] Vehicle Technologies Office, Energy Storage R\&D, Fiscal Year 2012 Annual Progress Report, United States Department of Energy, Washington, DC, http://www1.eere.

energy.gov/vehiclesandfuels/resources/vt_e s_fy12.html, January 2013, accessed on 2012-06-25.

[7] Office of Vehicle Technologies, Vehicle and Systems Simulation and Testing, Fiscal Year 2012 Annual Progress Report, Washington, DC, January 2013, http://www1.eere.

energy.gov/vehiclesandfuels/pdfs/program/ 2012_vsst_report.pdf, accessed on 2013-0625.

[8] Office of Vehicle Technologies, Advanced Power Electronics, Fiscal Year 2012 Annual Progress Report, U.S. Department of Energy, Washington, DC, January 2013, http://www1.eere.energy.gov/vehiclesandfu els/pdfs/program/2012_apeem_report.pdf, accessed on 2013-06-25.

[9] The EV Everywhere Grand Challenge Blueprint, http://www1.eere.energy.gov/ vehiclesandfuels/electric_vehicles/pdfs/eve verywhere blueprint.pdf, accessed on 201306-20.
[10] The White House Press Release, Grants to Accelerate the Manufacturing and Deployment of the Next Generation of U.S. Batteries and Electric Vehicles, August 5, 2009. http://www.whitehouse.gov/the-pressoffice/24-billion-grants-acceleratemanufacturing-and-deployment-nextgeneration-us-batter

[11] United States Advanced Batteries Consortium, USABC Electric Vehicle Battery Test Procedure Manual, Rev. 2, U.S. D.O.E., DOE/ID 10479, January 1996.

[12] U.S. Department of Energy, PNGV Battery Test Procedures Manual, Rev. 2, August 1999, DOE/ID-10597.

[13] U.S. Council for Automotive Research, RFP and Goals: Advanced Battery Development for PEVs, http://www.uscar. org/, accessed on 2012-02-29.

[14] Berkeley Electrochemical Research Council, Batteries for Advanced Transportation Technologies, Lawrence Berkeley National Lab, http://berc.lbl.gov/BATT/BATT.html, accessed on 2012-02-29.

[15] SAE J1772: EV and PHEV Conductive Charge Coupler:accessed on 2013-06-20 http://www.sae.org/servlets/pressRoom?OBJ ECT_TYPE=PressReleases\&PAGE=showRel ease\&RELEASE ID=1897.

\section{Author}

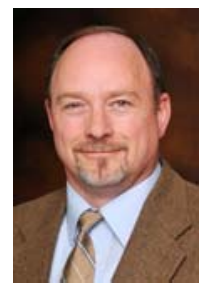

David Howell

U.S. Department of Energy

1000 Independence Avenue, SW

Washington, DC 20585 (USA)

Tel: 202-586-3148

Fax: 202-586-2476

Email: David.Howell@ee.doe.gov

David Howell is the Team Leader for the Hybrid Electric Systems Team at the DOE Vehicle Technologies Office. $\mathrm{He}$ received his B.S. degree in Aerospace Engineering from the University of Tennessee in Knoxville, TN. 